\title{
Correction to: Genome-wide development of insertiondeletion (InDel) markers for Cannabis and its uses in genetic structure analysis of Chinese germplasm and sex- linked marker identification
}

Gen Pan ${ }^{1,2+}$, Zheng $\mathrm{Li}^{1 \dagger}$, Siqi Huang ${ }^{1,2}$, Jie Tao ${ }^{1}$, Yaliang Shi ${ }^{1}$, Anguo Chen ${ }^{1,2}$, Jianjun Li ${ }^{1,2}$, Huijuan Tang ${ }^{1,2}$, Li Chang ${ }^{1,2}$, Yong Deng ${ }^{1,2}$, Defang $\mathrm{Li}^{1,2^{*}}$ and Lining Zhao ${ }^{1,2^{*}}$

Correction to: BMC Genomics 22, 595 (2021)

https://doi.org/10.1186/s12864-021-07883-w

Following publication of the original article [1], it was reported that Fig. 2 was a duplicate of Fig. 3. The correct Fig. 2 is provided in this Correction article and the original article has been updated.

\section{Author details}

${ }^{1}$ Institute of Bast Fiber Crops, Chinese Academy of Agricultural Sciences, Changsha 410205, China. ${ }^{2}$ Key Laboratory of the Biology and Process of Bast Fiber Crops, Ministry of Agriculture, Changsha, China.

Published online: 13 September 2021

\section{Reference}

1. Pan G, Li Z, Huang S, et al. Genome-wide development of insertion-deletion

(InDel) markers for Cannabis and its uses in genetic structure analysis of Chinese germplasm and sex-linked marker identification. BMC Genomics. 2021;22:595 https://doi.org/10.1186/s12864-021-07883-w.

\footnotetext{
The original article can be found online at https://doi.org/10.1186/s12864021-07883-w.

*Correspondence: chinakenaf@126.com; csbtzIn@163.com

${ }^{+}$Gen Pan and Zheng Li contributed equally to this work.

'Institute of Bast Fiber Crops, Chinese Academy of Agricultural Sciences, Changsha 410205, China

Full list of author information is available at the end of the article
}

C C The Author(s). 2021 Open Access This article is licensed under a Creative Commons Attribution 4.0 International License, which permits use, sharing, adaptation, distribution and reproduction in any medium or format, as long as you give appropriate credit to the original author(s) and the source, provide a link to the Creative Commons licence, and indicate if changes were made. The images or other third party material in this article are included in the article's Creative Commons licence, unless indicated otherwise in a credit line to the material. If material is not included in the article's Creative Commons licence and your intended use is not permitted by statutory regulation or exceeds the permitted use, you will need to obtain permission directly from the copyright holder. To view a copy of this licence, visit http://creativecommons.org/licenses/by/4.0/ The Creative Commons Public Domain Dedication waiver (http://creativecommons.org/publicdomain/zero/1.0/) applies to the data made available in this article, unless otherwise stated in a credit line to the data. 


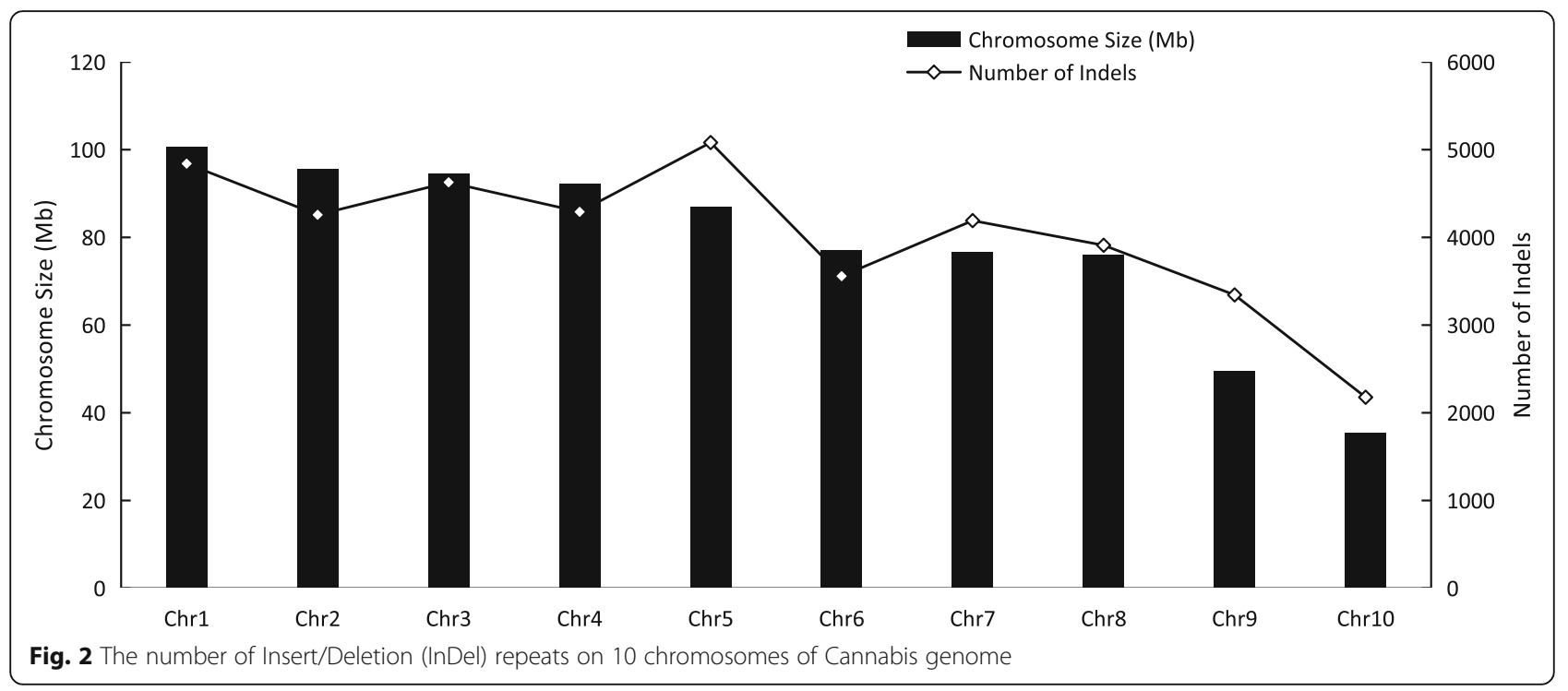

